\title{
Primary Calvarial Tuberculosis Presenting with Scalp Swelling and Lytic Bone Lesion: A Case Report
}

\author{
Parietal Bölgede Saçlı Deride Şişlik ve Litik Kemik ile Presente Olan Primer \\ Tüberküloz Olgusu: Bir Olgu Sunumu
}

\author{
๑ Aykut Akpınar, ๑ Uzay Erdoğan, ๑ Murat Koçyiğit \\ University of Health Sciences, Haseki Training and Research Hospital, Clinic of Neurosurgery, Istanbul, Turkey
}

\begin{abstract}
Calvarial tuberculosis is a rare entity in developed countries. Even though it is a rare occurrence, the incidence of calvarial tuberculosis is increasing in developed countries because of migration from developing countries with poor socio-economic conditions, shortage of food, and high prevalence of immunodeficiency diseases. The disease mostly involves frontal and parietal bones and presents with painless swelling of the scalp. Plain X-ray and computed tomography scans show lytic calvarial lesions, and both computed tomography and magnetic resonance imaging can demonstrate parenchymal involvement of soft tissue. Surgery and antitubercular therapy are classical treatments. We present a 33-year-old male with painless scalp swelling and a lytic bone lesion.
\end{abstract}

Keywords: Calvarium, osteitis, tuberculoma, extrapulmonary tuberculosis
Öz

Kafatası kemiklerinin tüberkülozu gelişmiş ülkelerde nadir bir olgudur. Nadir görülmesine rağmen, gelişmekte olan ülkelere göç edenlerde, yetersiz sosyo-ekonomik durumlar ve immün yetmezlik sendromları nedeniyle gelişmiş olan ülkelerde tüberküloz görülme sıklı̆̆ yükselmektedir. Genellikle frontal ve parietal kemikleri içerir ve kafatası derisinde ağrısız şişlik ile var olur. Direkt grafi ve bilgisayarlı tomografide litik kafatası lezyonları görülür, hem bilgisayarlı tomografi ve hem de manyetik rezonans görüntülemede yumuşak doku ile karışan parenkim gözlenmektedir. Cerrahi usul ve antitüberküloz ilaçlar standart tedavidir. Biz 33 yaşındaki erkek hastada saçı deride ağrısız şişlik ve litik kemik lezyonunu olgu takdimi olarak sunmaktayız.

Anahtar Sözcükler: Kafatası, kemik yangısı, tüberküloma, akciğer dışı tüberküloz

About $70-90 \%$ of patients suffering from calvarial TB fall under the age of 20 years, and patients are mostly between the age of 11 to 20 years $(3,4)$. The male-tofemale ratio is $2: 1$. Calvarium punched-out lytic lesions with painless swelling are usual forms $(2,4,6)$.

TB may affect inside and outside the calvarial bones and epidural and subgaleal regions (4). It usually involves the frontal and parietal bones because of the greater amount of cancellous bone with diploic channels (6). Parietal bone is the most affected site of the calvarium $(2,4,6)$.

The diagnosis relies upon a good clinical acumen and timely radiological investigations. X-ray and cranial computed tomography (CT) reveal punched-out areas in the skull bones (mostly frontal and parietal ones) $(2,4,6)$.
Address for Correspondence/Yazışma Adresi: Aykut Akpınar

University of Health Sciences, Haseki Training and Research Hospital, Clinic of Neurosurgery, Istanbul, Turkey

Phone: +90 5336109583 E-mail: aykut1953@yahoo.com ORCID ID: orcid.org/0000-0002-5049-3259 Received/Geliş Tarihi: 02 November 2017 Accepted/Kabul Tarihi: 30 January 2018
Copyright 2018 by The Medical Bulletin of University of Health Sciences Haseki Training and Research Hospital
The Medical Bulletin of Haseki published by Galenos Yayınevi.

Telif Hakkı 2018 Sağlik Bilimleri Üniversitesi Haseki Eğitim ve Araştırma Hastanesi Haseki Tıp Bülteni, Galenos Yayınevi tarafından basılmışıı. 
Magnetic resonance imaging (MRI) shows soft tissue changes. Isolation of bacilli is quiet diagnostic, which is not possible most of the time. Surgery and antitubercular therapy are the mainstay of treatment (2).

\section{Case}

A 33-year-old male presented with the complaints of slowly growing swelling in the right frontoparietal region and headache. He had no fever and lose flesh. He had no history of head trauma as well. On examination, the fluctuating scalp swelling lesion size was $2 \times 1 \times 1.5 \mathrm{~cm}$ in size. A small defect was palpable in the parietal region. A punched-out lesion was seen on plain $\mathrm{X}$-ray (Figure 1). Initial CT scan of the head revealed a bone defect involving the inner and outer tables (Figure 2). MRI
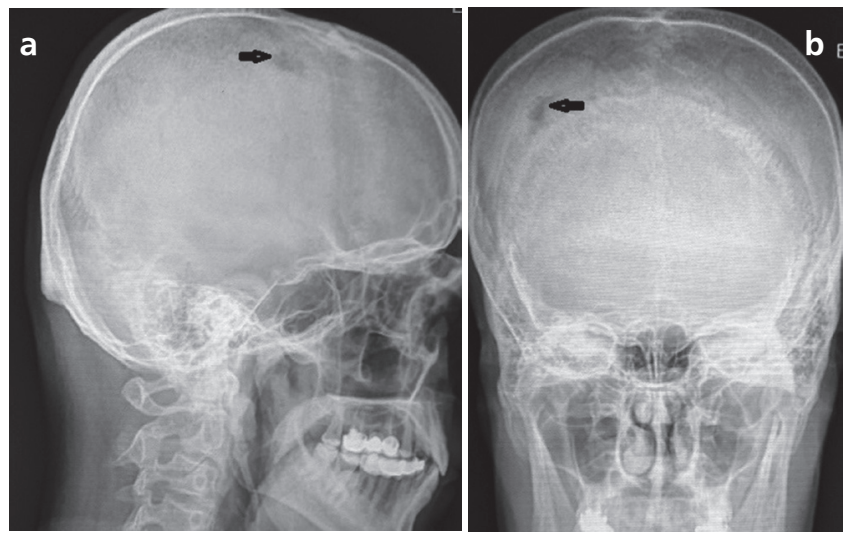

Figure 1. a-b) Anterior to posterior and lateral X-ray view of skull showing lytic lesion

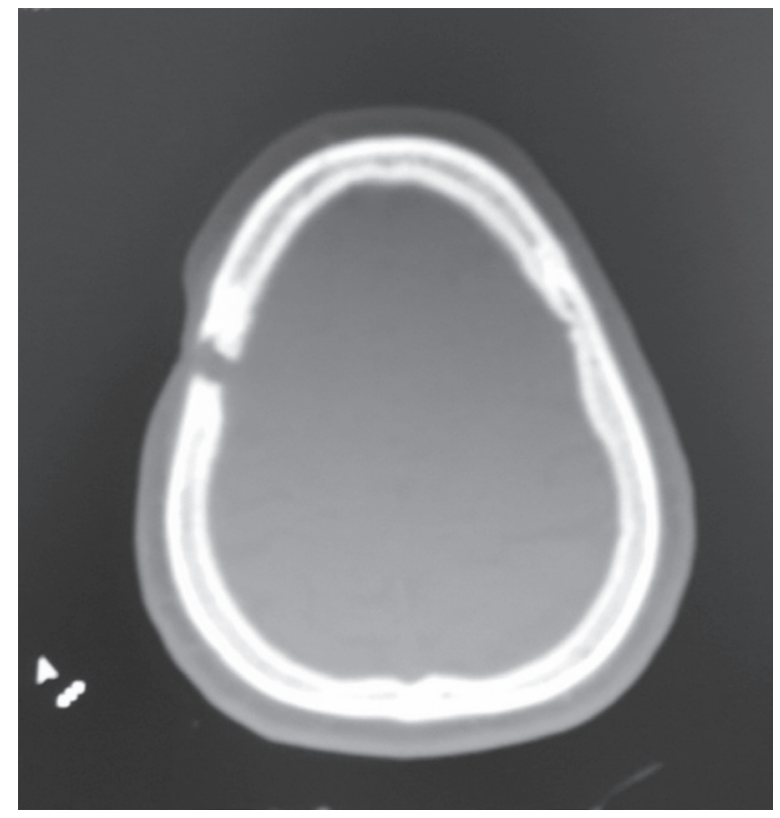

Figure 2. Axial computed tomography scan showing calvarial defect and hyperintensity of lesion revealed a T1 hypointense and T2 hypertense well-defined lesion situated between the scalp and the extradural area (Figure 3). His chest X-ray was unremarkable. There was no leukocytosis, and erythrocyte sedimentation rate (ESR) was normal. Mantoux tuberculin skin test (TST) revealed an induration of greater than $10 \mathrm{~mm}$. Informed consent was received from the patient and his family.

Under local anesthesia, an excisional biopsy was done, and we detected a lytic bone lesion with yellowish caseating material. Soft granulomatous tissue was excised till the dura layer. After debridement, saline and betadine irrigation were done and the wound was closed.

Histopathological examination showed scattered Langhans giant cells, scattered mature lymphocytes, and plasma cells (Figure 4). No malignant cells were observed, and special stains for acid-fast bacilli were negative.

The postoperative period was uneventful. Antitubercular treatment with the combination of isoniazid, rifampin, pyrazinamide, and streptomycin was administered for nine months.

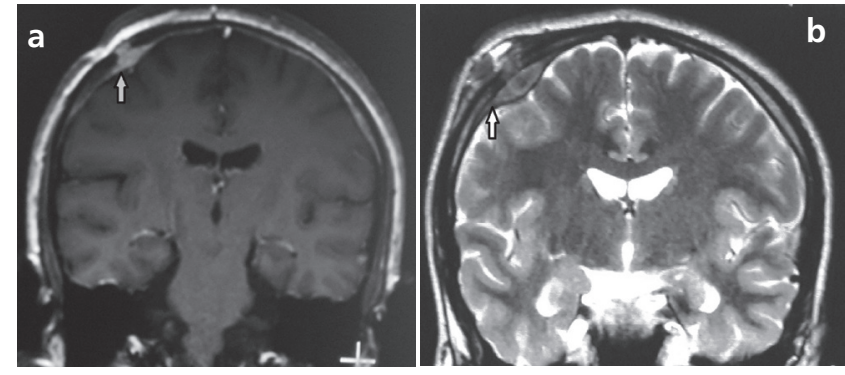

Figure 3. a) Contrast-enhanced Coronal $\mathrm{T} 1$ weighted magnetic resonance imaging shows parietal hyperintensity between scalp and dura. b) Coronal T2 weighted magnetic resonance imaging shows the lesion

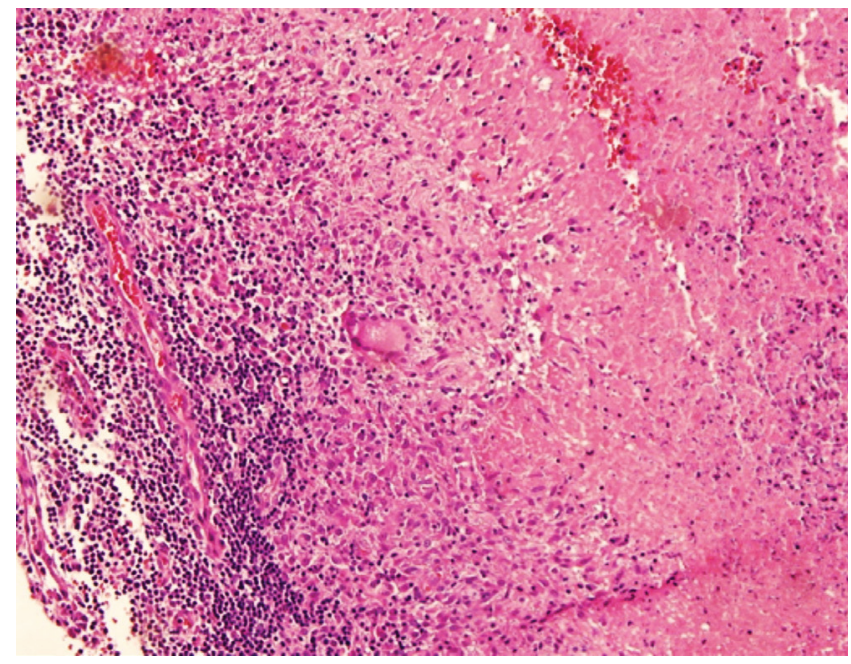

Figure 4. Histopathological examination: 20x hematoxylin eosin, Langhans giant cells, caseous granulomas, multiple epitheloid, and polymorphonuclear cells with vessels 


\section{Discussion}

MTB is still a serious health problem in Turkey (as a developing country) because of migration, pollution, malnutrition, social and economic problems. Calvarial $T B$ is a rare manifestation of extrapulmonary $T B$, and it constitutes $0.1-3.7 \%$ of all skeletal TB cases $(2,4,5)$.

Isolated calvarial TB is rare, and it mostly arises with metastasis of primary lesion through hematogenous spread. Most cases are secondary to pulmonary TB. Primary TB may affect the whole body (7).

Calvarial TB arises from bacilli seeding from diploic channels, while the balance of virulence and host immune response changes capillary obliteration and granulation begins through fibroblasts (8). Frontal and parietal bones are often affected due to the greater amount of cancellous bone with diploic channels in these bones, however, occipital and spheoid bones are less frequently affected $(2,9,10)$. Dura mater is highly resistant to invasion $(5,6)$.

It has been reported that calvarial TB was mostly seen in young population (6). It is more prevalent in males than in females, and trauma is a predisposing factor $(3,4)$. The patient had painless fluctuant scalp swelling $(4,6)$. The lesion is together with the same side headache (11). Our patient was a 33-year-old male. There was no history of trauma, and one lytic lesion was found.

Plain X-ray and CT are useful to observe punch-out defects. There may be osteolytic and osteoblastic reactions $(4,9)$. The sensitivity of conventional radiography and CT has been found to be $80.95 \%$, and $85.7 \%$, respectively (4). CT and MRI help detecting intraparenchymal pathologies and extradural lesions. MRI has a higher degree of sensitivity, especially with soft tissue lesions $(4,12)$. We used all these imaging modalities.

Primary or secondary calvarial carcinomas and benign cystic lesions should be considered in the presence of lytic lesions of the calvarium $(4,5)$.

On histopathological examination, the presence of caseous granulomas verifies the diagnosis of TB. Detection of acid-fast bacilli and isolation by culture are diagnostic but often negative $(13,14)$. We detected lymphocytes and Langhans giant cells, but not bacilli.

Fever, high ESR, positive TST (+), and CT, MRI and X-ray findings and pathology can help establish the diagnosis of TB (3). Negative TST without high ESR has been reported in $10 \%$ of patients $(2,14)$. Our patient had a ESR value of within the normal range. There was no fever or weight loss, but the tuberculin test was positive.

The management of calvarial TB includes both surgery and antitubercular therapy (4). If there are mass effects, neurological deficits, abscesses, and cosmetic problems, surgery is the main modality (15). Biopsy helps determine the etiology and decide on medical treatment. Antitubercular therapy should be given at least for nine months $(4,10)$.

Primary TB rarely affects the calvarium, however, the incidence of TB is increasing. Conventional radiography and $\mathrm{CT}$, as well as MRI are usefull in establishing the diagnosis. If there is, mass effect, neurological deficits, abscesses, and/or cosmetic problems, surgery may be the main modality. Biopsy is always helpful in the diagnosis. The management of calvarial TB includes both surgery and antitubercular therapy.

\section{Authorship Contributions}

Surgical and Medical Practices: A.A. Concept: A.A., U.E. Design: A.A., M.K. Data Collection or Processing: A.A., U.E., M.K. Analysis or Interpretation: A.A., M.K. Literature Search: A.A., U.E., M.K. Writing: A.A.

Conflict of Interest: No conflict of interest was declared by the authors.

Financial Disclosure: The authors declared that this study received no financial support.

\section{References}

1. Dawar P, Satyarthee GD, Sharma BS. Total Resolution of Large Scalp Swelling due to Calvarial Tuberculosis with Medical Management Only: Case Report and Review of the Literature. Turk Neurosurg 2015;25:313-6.

2. Diyora B, Kumar R, Modgi R, Sharma A. Calvarial tuberculosis: A report of eleven patients. Neurology India 2009;57:607-12.

3. LeRoux PD, Griffin GE, Marsh HT, Winn HR. Tuberculosis of the skull-a rare condition: case report and review of the literature. Neurosurgery 1990;26:851-5.

4. Raut AA, Nagar AM, Muzumdar D, et al. Imaging features of calvarial tuberculosis: a study of 42 cases. AJNR Am J Neuroradiol 2004;25:409-14.

5. Gupta PK, Kolluri VR, Chandramouli BA, Venkataramana NK, Das BS. Calvarial tuberculosis: a report of two cases. Neurosurgery 1989;25:830-3.

6. Mohanty S, Rao CJ, Mukherjee KC. Tuberculosis of the skull. Int Surg 1981;66:81-3.

7. Tata HR. Tuberculous osteomyelitis of the skull. Indian J Tuberculosis 1978;25:208-9.

8. Malhotra R, Dinda AK, Bhan S. Tubercular osteitis of skull. Indian Pediatr 1993;30:1119-23.

9. Patankar T, Varma R, Krishnan A, Prasad S, Desai K, Castillo M. Radiographic findings in tuberculosis of the calvarium. Neuroradiology 2000;42:518-21.

10. Ramdurg SR, Gupta DK, Suri A, Sharma BS, Mahapatra AK. Calvarial tuberculosis: Uncommon manifestation of common disease-a series of 21 cases. Br J Neurosurg 2010;24:572-7.

11. Mukherjee KK, Kaushik R, Nada R, Khosla VK, Khandelwal N, Kak VK. Calvarial tuberculosis. Surg Neurol 2002;57:195202. 
12. Al Wohaibi $M$, Russell NA, Omojola M, Al Ferayan A. Tuberculosis of the skull. Case illustration. J Neurosurg 2000;92:1065.

13. Rajmohan BP, Anto D, Alappat JP. Calvarial tuberculosis. Neurol India 2004;52:278-9.

14. Fisk TL, Hon HM, Lennox JL, Fordham von Reyn C, Horsburgh CR Jr. Detection of latent tuberculosis among HIV-infected patients after initiation of highly active antiretroviral therapy. AIDS 2003;17:1102-4

15. Shahat AH, Rahman NU, Obaideen AM, Ahmed I, Zahman Au Au. Cranial-epidural tuberculosis presenting as a scalp swelling. Surg Neurol 2004;61:464-6. 